to work by rapidly triggering one arm of the immune system to hold back the virus while the body ramps up antibody production, according to a study in monkeys.

Heinz Feldmann of the National Institute of Allergy and Infectious Diseases in Hamilton, Montana, and his colleagues tested the VSV-EBOV vaccine, which was designed to fight the 2014 West African outbreak strain of Ebola virus. The team immunized 15 rhesus macaques (Macaca mulatta) and then infected them with the virus. All but one of the vaccinated animals survived, whereas all unimmunized animals died about a week after infection.

Analysis of the surviving animals' blood showed that the vaccine triggered the innate immune system to keep viral replication in check during the first days of infection, giving the rest of the immune system time to churn out Ebola-specific antibodies. Science http://doi.org/6p9 (2015)

\section{GEOLOEY}

\section{Why Nepal quake was so damaging}

The magnitude-7.8 earthquake that devastated much of Nepal on 25 April did not relieve all of the geological stress in the region - making another big quake probable.

A team led by Jean-Philippe Avouac at the University of

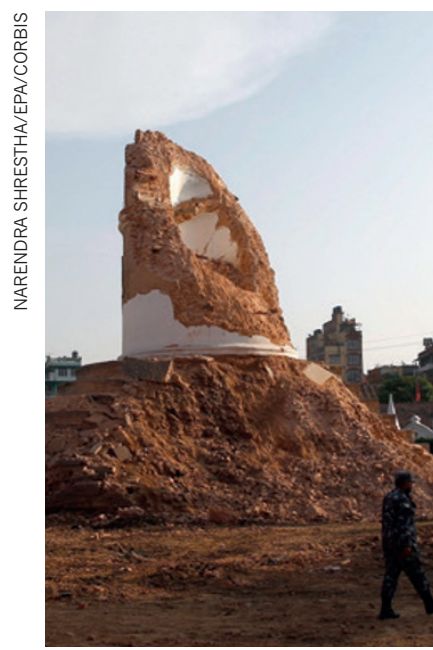

Cambridge, UK, used seismic data and satellite radar to show that a 140-kilometre stretch of a major Himalayan geological fault shifted during the disaster. This transferred stress into neighbouring areas of the fault, which may now be more prone to rupturing in a future quake.

In a separate paper, Yuji Yagi and Ryo Okuwaki of the University of Tsukuba, Japan, found that the earthquake rupture raced eastward from its point of origin. The greatest movement of the fault occurred about 50 kilometres east of the quake's epicentre - close to Kathmandu.

This discovery helps to explain why the shaking was so destructive to the city, according to a third paper by another team led by Avouac. Although much of the ground in the region shook only moderately, the seismic energy was amplified across the Kathmandu basin in ways that caused tall buildings, including temples, to sway and collapse (pictured is what remains of Kathmandu's Bhimsen Tower, known as Dharahara).

Nature Geosci. http://doi.org/6p7 (2015); Geophys. Res. Lett. http:// doi.org/6ns (2015); Science http://doi.org/6p6 (2015)

\section{CELL BIOLOGY}

\section{Chemicals switch cells' identity}

Adult skin cells have been transformed directly into neurons by two independent groups in China using just small-molecule chemicals.

Reprogramming adult cells back into stem cells or directly into other types of specialized cells requires transcription factors, which modify cells genetically. To avoid tinkering with the cells' genes, Gang Pei and Jian Zhao from the Shanghai Institutes for Biological Sciences and their colleagues worked with fibroblasts, or skin cells, from both healthy adults and people with Alzheimer's disease, culturing them with a cocktail

\title{
SOCIAL SELECTION
}

\section{Bioethics comes under fire}

The latest biomedical technologies, from fetal stem cells to human gene editing, offer huge potential for treating disease. They also raise tricky ethical questions that can eventually result in guidelines on how to prevent their misuse. In an opinion piece in The Boston Globe, Harvard University psychologist Steven Pinker argues that this sweeping ethical oversight delays innovation and should 'get out of the way' (go.nature.com/93t5ti). The article ignited much discussion on social media among bioethicists and researchers. Many disagreed with Pinker, including Daniel Sokol, a London-based bioethicist and lawyer, who wrote in a blog post that ethicists should at times 'get in the way' (see

$\begin{array}{ll}\text { DNATURE.COM } & \text { go.nature.com/zmluki). Research to } \\ \text { For more on } & \text { he added, but "misguided attempts } \\ \text { popular papers: } & \text { to help can - and have - led to } \\ \text { go.nature.com/b6jxzu } & \text { incalculable harm". }\end{array}$

of small molecules to produce neurons.

Hongkui Deng at Peking University, Beijing, and his colleagues used a different set of chemicals to convert mouse fibroblasts into neurons. Both groups made neurons that looked, fired and made functional connections just like neurons created from fibroblasts using transcription factors.

The chemicals modulate key molecular signalling pathways to change an adult cell's identity. This approach could make it easier to reprogram cells for clinical use, say the authors.

Cell Stem Cell http://doi.org/6p4; Cell Stem Cell http://doi.org/6p5 (2015)

\section{ZOOLOGY \\ Venomous frogs headbutt foe}

Two Brazilian frog species use sharp spines protruding from around their noses and mouths to deliver toxins in their skin to predators - the first evidence of a venomous frog.

Most frogs produce toxins in their skin but have no way of deliberately passing them on to predators. Edmund Brodie at Utah State University

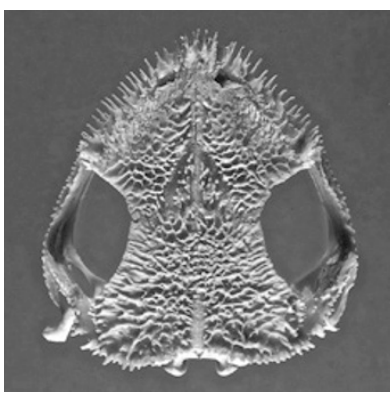

in Logan and his team discovered this toxin delivery when they were collecting specimens of two tree-frog species (Corythomantis greeningi and Aparasphenodon brunoi) and restraining them in their hands. C. greeningi (skull, pictured) jabbed its spiny head into the offending hand and released toxins from its skin glands, causing intense pain in the arm for several hours. When tested in mice, the venom from both frog species caused swelling and was deadly at high concentrations.

There could be more venomous amphibians than thought, the authors say. Curr. Biol. http://doi.org/6n7 (2015)

\section{$\rightarrow$ NATURE.COM}

For the latest research published by Naturevisit:

www.nature.com/latestresearch 